\title{
Land-sea correlation between Late Holocene coastal and infralittoral deposits in the SE lberian Peninsula (Western Mediterranean)
}

\author{
L.M. Fernández-Salas ${ }^{\text {a,* }}$, C.J. Dabrio ${ }^{\text {b }}$, J.L. Goy ${ }^{\text {c }}$, V. Díaz del Río ${ }^{\text {a }}$, C. Zazo ${ }^{\text {d, F.J. Lobo }}{ }^{\text {e }}$, J.L. Sanz ${ }^{\text {f }}$, J. Lario ${ }^{\mathrm{g}}$ \\ a Instituto Español de Oceanografia, 29640 Fuengirola, Spain \\ - Departamento de Estratigrafia É Instituto de Geología Económica, Universidad Complutense, 28040 Madrid, Spain \\ ${ }^{\circ}$ Departamento de Geologia, Universidad de Salamanca, 37008 Salamanca, Spain \\ d Departamento de Geología, Museo Nacional de Ciencias Naturales, CSIC, 28006 Madrid, Spain \\ e Instituto Andaluz de Ciencias de la Tierta, CSIC-Universidad de Granada, 18002 Granada, Spain \\ Instituto Español de Oceanografia, 28002 Madrid, Spain \\ \& Departamento de Ciencias Analíticas, Facultad de Ciencias, Universidad Nacional de Educación a Distancia (UNED), 28040-Madrid, Spain
}

A R T I C L E I N F O

\section{Article history:}

Accepted 26 March 2008

Available online 23 May 2008

\section{Keywords:}

Infralittoral prograding wedge

Beach-ridge progradation complex

Alborán Sea

Holocene

Swath bathymetry

\begin{abstract}
A B S T R A C T
The well-exposed systems of prograding beach ridges on the Carchuna-Calahonda (Granada) and Campo de Dalías-Roquetas (Almería) coastal plains continue offshore as infralittoral prograding wedges (IPW). The Holocene IPW is a narrow morpho-sedimentary unit up to $2.5 \mathrm{~km}$ wide which develops seaward from the lower edge of the shoreface to $15-20 \mathrm{~m}$ depth, extending to a well-defined break of slope at water depths of $35-40 \mathrm{~m}$. These IPWs have been recognized and studied using very high-resolution seismic profiles (TOPAS) and multibeam data (EM-3000D). In detail they are complex morpho-sedimentary units in which internal structures are closely linked to the pattern of progradation of the adjacent coastal plains. When longshore currents produce significant littoral drift, the IPWs are composed of several minor units arranged in offlap, which accrete parallel or oblique to the main shoreline. Therefore, it is possible to correlate progradational units in the coastal plain (H-units, sensu[Goy, J.L., Zazo, C., Dabrio, C.J., 2003. A beach-ridge progradation complex reflecting periodical sea-level and climate variability during the Holocene (Gulf of Almería, Western Mediterranean). Geomorphology 50, 251-268]) and subunits in the IPW, but special care is required depending on the local arrangement of morpho-sedimentary units. Besides, it is not realistic to draw conclusions regarding the age of the subunits inside a given IPW without adequate dating, as the number of subunits will greatly vary from place to place depending on local factors, magnitude of sea-level oscillations, and sediment supply.
\end{abstract}

\section{Introduction}

Most models of beach-nearshore sedimentation consider that beach-face deposits evolve laterally seawards into finer grained deposits where the signature of wave action is more or less progressively weaker until finally the grain size becomes silt-clay. In these models the sandy foreshore facies wedge out across the shoreface into the muddy facies of the shelf (e. g.: Swift and Thorne, 1991; Swift et al., 1972, 1991).

In contrast, detailed studies along the south and south-eastern coasts of the Iberian Peninsula (Hernández-Molina et al., 2000) revealed the existence of a wedge of relatively coarser sediments in the infralittoral domain, the so-called infralittoral prograding wedge (IPW) that is interpreted as formed by storm-generated currents (downwelling currents) which produce a seaward sediment transport.
Late Holocene infralittoral prograding wedges (IPW) have been described in the shallow waters of Granada and Almería provinces in southern Spain, seawards from the lower edge of the shoreface, and not linked to major fluvial sources (Hernández-Molina et al., 2000). The IPW in this area occurs as a narrow body elongated parallel to the main shoreline, and it is thought to have developed during the last highstand system tract of the last fourth-order cycle which took place during the last 6500 years BP (Hernández-Molina et al., 1994, 2000; Somoza et al., 1998; Dabrio et al., 2000; Hernández-Molina and Lobo, 2005; Lobo et al., 2005). A major drawback of these studies is the poor knowledge of the age of the units recognized in seismic surveys, which greatly impedes accurate correlations with beach deposits of similar ages.

As there are well studied examples of prograding coastal plains and spit bars in this same geographical area (e. g.: Zazo et al., 1994; Lario et al., 1999; Rodríguez-Ramírez et al., 2000; Goy et al., 2003) that have been mapped carefully and dated by means of $14-\mathrm{C}$, it seems interesting to relate these morpho-sedimentary units with the IPW, as a means of better understanding Holocene evolution of the coastal domain. Probably the best on-land example of a prograding coastal 
plain with preserved beach ridges in the Western Mediterranean is the Campo de Dalías, in Almería Province (Goy et al., 2003). The main features of this case study are incorporated in this work.

In summary, the aim of this paper is to present the results of seismic and bathymetric surveys in the shallow nearshore zone along the south-eastern coast of Spain, carried out in the framework of the ESPACE geological program, and to evaluate whether or not the IPW can be correlated with the emergent coastal sequences along the same coastal tracts.

\section{Regional setting}

The nearshore areas studied are located on the northern margin of the Alborán Sea (Western Mediterranean) off the coastal plains of

A

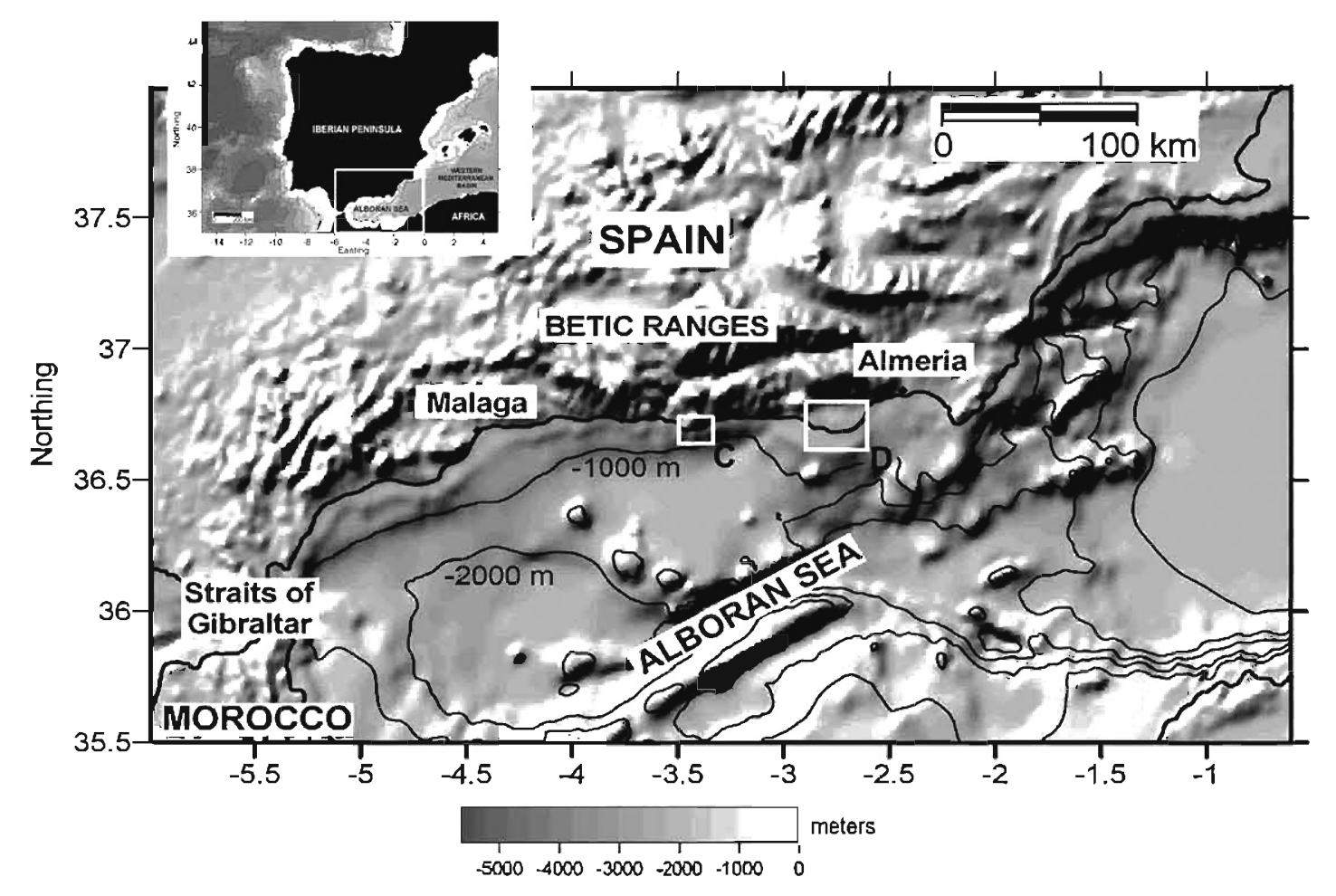

$\mathrm{B}$

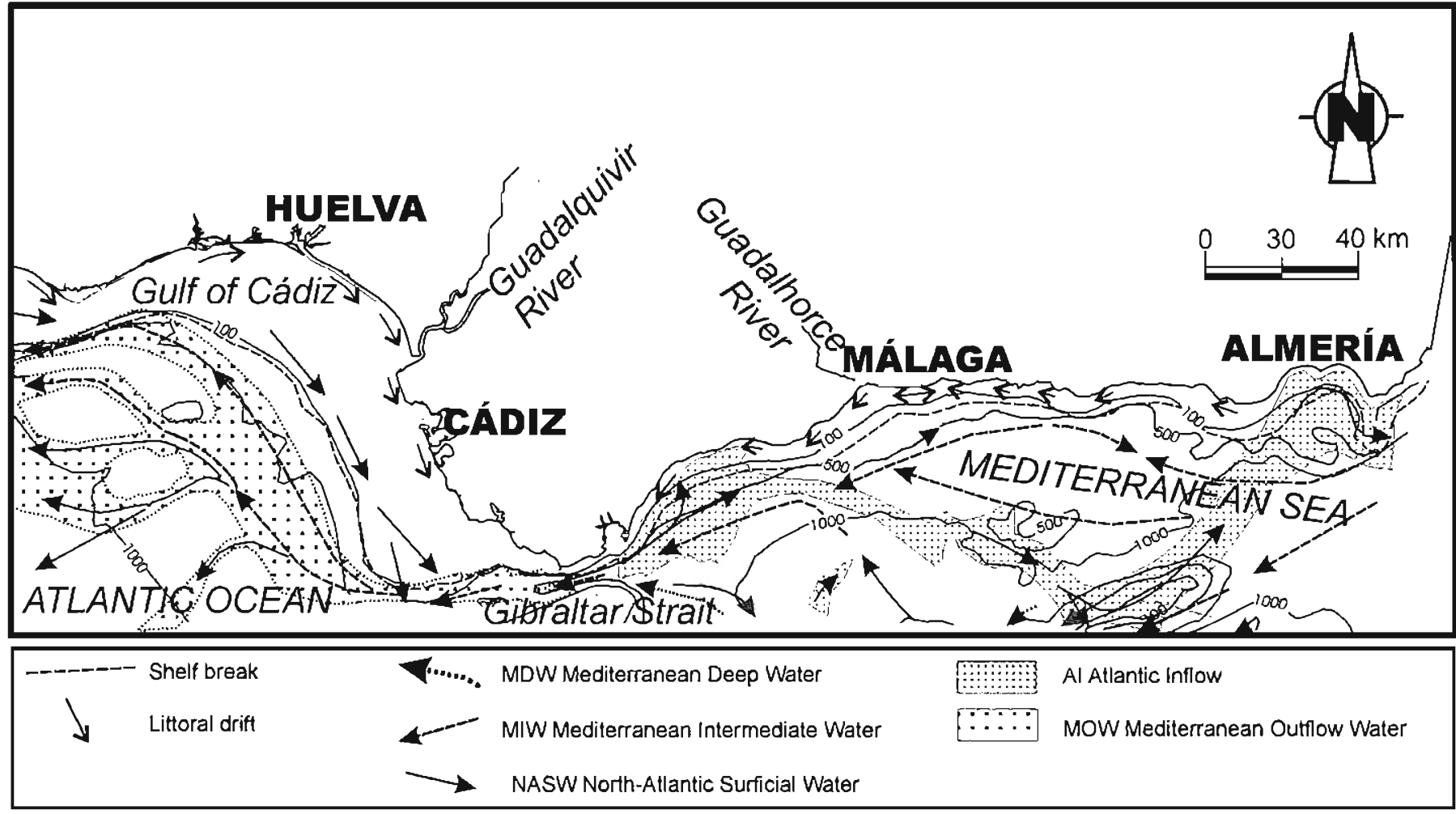

Fig. 1. Geographical location of the study areas: A) map of northern margin of the Alborán Sea in the Western Mediterranean Sea, off the Betic Ranges. Study areas are marked with white boxes (C: Carchuna, D: Dalías. B) Oceanographic setting showing water masses and currents systems (modified from Hernández-Molina, 1993). 
Carchuna-Calahonda (Granada) and Campo de Dalías-Roquetas (Almería) (Fig. 1) that have been described and dated in previous papers (Lario et al., 1999 and Goy et al., 2003, respectively).

The area is located in the subtropical high-pressure cell of the NE Atlantic and experiences a markedly seasonal Mediterranean climate, with cool winters and hot, dry summers. Most of the scarce rain (average $200-300 \mathrm{~mm}$ ) is of cyclonic origin and related to prominent contrasts of temperatures between land and sea.

The structurally-controlled coast extends in an E-W direction (Fig. 1A), roughly parallel to the prevailing winds, a configuration prone to the generation of longshore currents and littoral drift, as the winds usually persist for several days. Warm, moist winds from the east are particularly intense in autumn and winter and produce "sea" waves with heights usually $0.5-1 \mathrm{~m}$. Winds from the west predominate in spring and summer, favouring "swell" conditions, with wave heights up to $1.5-2.5 \mathrm{~m}$ (IHM, 1983).

The surface circulation pattern in the Alborán Sea depicts two anticyclonic gyres (Fig. 1B), the Western Alborán Gyre (WAG) and the Eastern Alborán Gyre (EAG) (Herburn and la Violette, 1990). The spatial pattern and the velocity of the inflow respond to long-term changes of sea level and to the intensity of thermohaline circulation. Winds from the $\mathrm{W}-\mathrm{SW}$ increase the velocity of the inflow and push the WAG to the east, up to the meridian of Almeria.

Most of the Holocene coasts in the study areas are prograding, reflective gravely beaches. Minor differences along the shore reflect local factors such as recent tectonic trends, amount and grain size of sediment input, and exposure to the prevailing winds and wave fronts (Goy et al., 2003). The coast is almost non-tidal, with astronomical tidal ranges less than $0.3 \mathrm{~m}$, but meteorological tides related to wind setup during storms exceed $1 \mathrm{~m}$ for periods of several days at a time, allowing larger wave run-ups and deposition of relatively high berms and beach crests in the steep beach faces.

Ephemeral rivers flowing into the littoral zone of Carchuna supply abundant gravel and sand to the coastal budget allowing continued progradation (Fig. 3). In contrast, the supply of sediment to the coasts of Campo de Dalías is compromised by neotectonic uplift which turned a large part of the area into an endorheic zone (Fig. 2). The only significant source areas during the Holocene were last-interglacial sandy to fine conglomeratic deposits exposed in low coastal cliffs (Fig. 4), and also the reworking of previous Holocene units.

\section{Material and methods}

The prograding beach-ridge complexes were mapped using several sets of aerial photographs at scales 1:33000 and 1:18000, and taken in various years from 1956 to 1990 . Field surveys were used to control the accuracy of the maps and also to collect samples of sediment and mollusc shells for ${ }^{14} \mathrm{C}$ analyses, in construction trenches and handdrilled excavations (Lario et al., 1999, Goy et al., 2003).

The shallow-water domain in the study area has been investigated with very high-resolution seismic profiles (TOPAS) and EM-3000D multibeam data (Fig. 2). TOPAS parametric echosounding provided a network of high-resolution seismic profiles oriented mainly NE-SW, $\mathrm{E}-\mathrm{W}$ and NW-SE. The spacing of profiles ranges from 4 to $10 \mathrm{~km}$. EM$3000 \mathrm{D}$ multibeam echo-sounder data cover $100 \%$ of the area from less than $5 \mathrm{~m}$ water depth in the shoreface to more than $170 \mathrm{~m}$ water depth in the open shelf. Multibeam data processed with the Neptune ${ }^{\circledR}$ software generated a $5 \times 5 \mathrm{~m}$ resolution grid.

All data were integrated in the ArcGIS $\otimes$ software suite. The bathymetric grid data allowed us to draw slopes, aspect and sunillumination maps, and also to perform morphologic analyses and quantitative measurements of submarine ridge and swale systems.

\section{Results}

\section{The prograding coastal plains}

The coastal plains of Carchuna-Calahonda (Fig. 3) (Lario et al., 1999) and Campo de Dalías-Roquetas (Fig. 4) (Goy et al., 2003) are formed by a succession of beach ridges and swales that reflect high-frequency oscillating sea levels: higher sea-levels produce ridges whereas comparatively lower sea-levels produce topographically-lower beach ridges that are observed as swales. Beach ridges were accumulated by wave/swash under essentially fair-weather conditions.

Morpho-sedimentary features and radiocarbon dating allowed Goy et al. (2003) to separate in Roquetas six prograding units (named $\mathrm{H}_{1}$ to $\mathrm{H}_{6}$ ) composed of bundles of sets of beach ridges. Adjacent $\mathrm{H}$-units can be separated by changes in set configuration (defined by the width and height of crests and the width of swales that form the sets), large swales or erosional surfaces (Fig. 4). There follows a brief excerpt from the paper by Goy et al. (2003), where these features were described

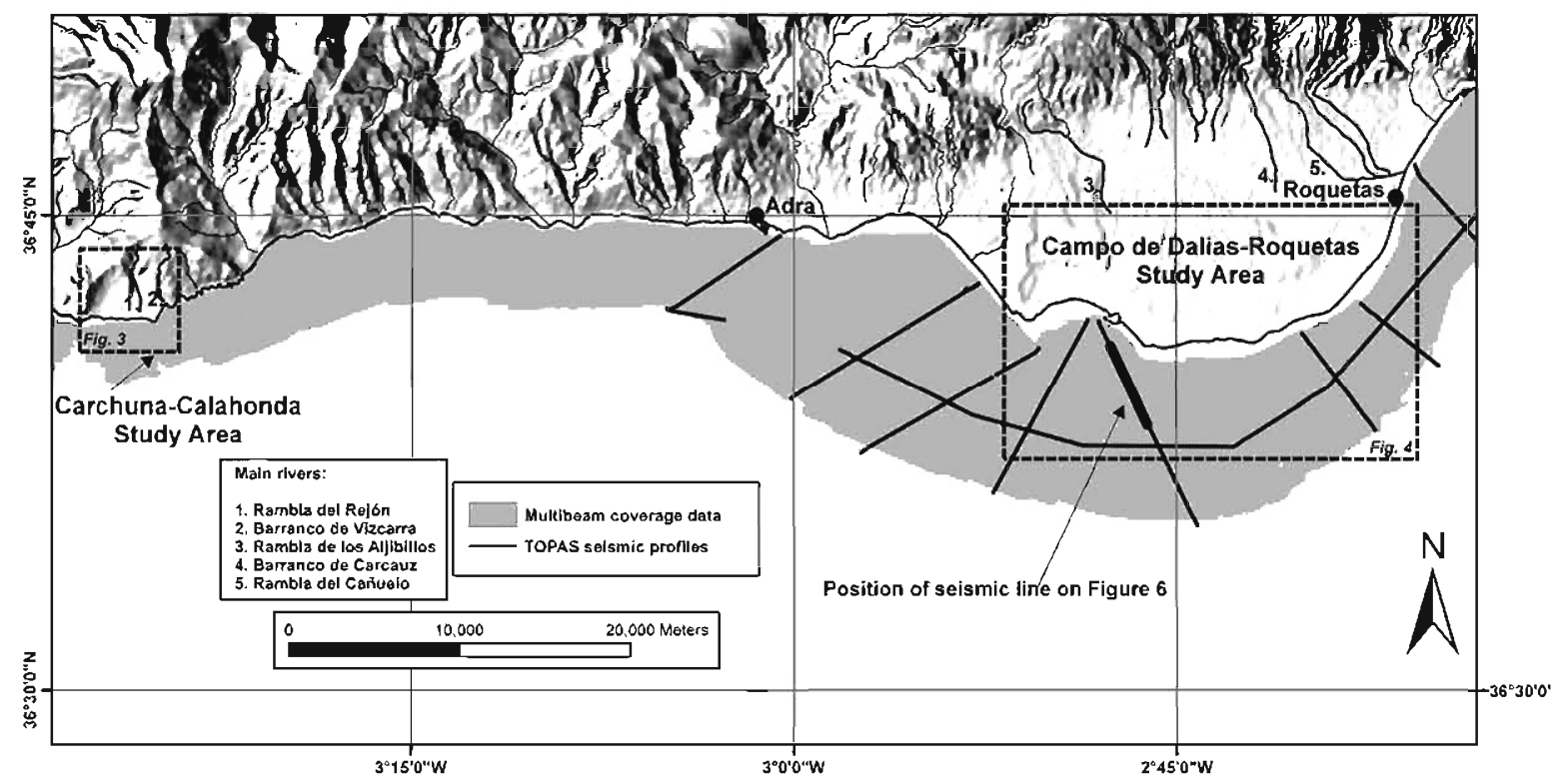

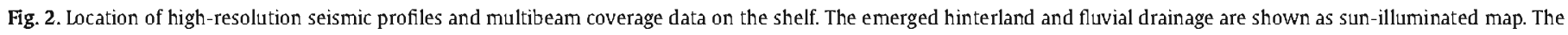
numbers indicate the main rivers supplying sediment to the study areas. 


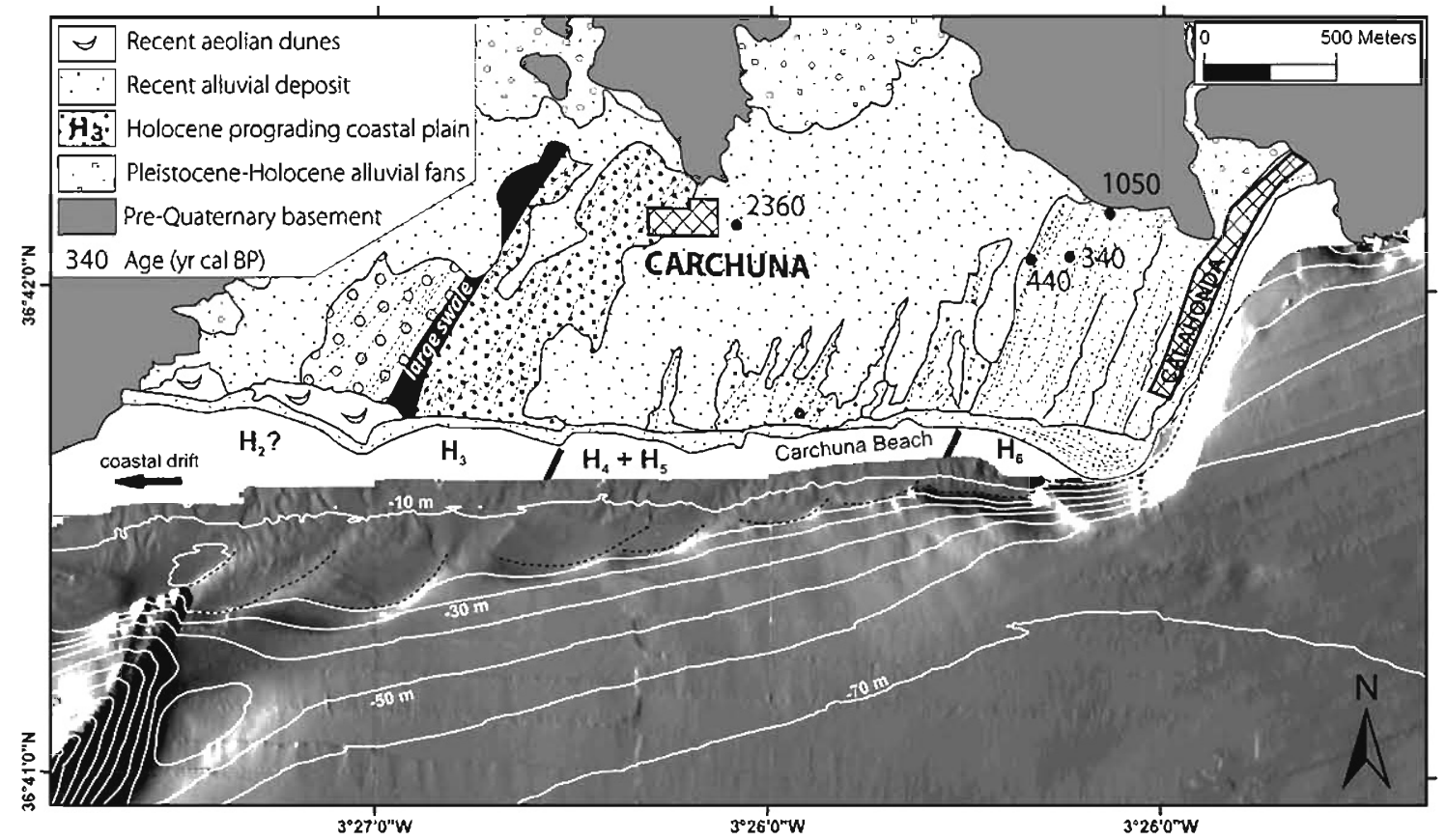

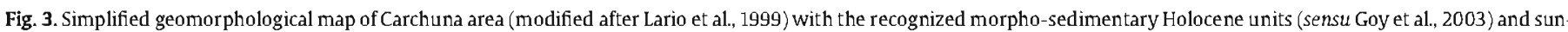
illuminated bathymetric map on the inner continental shelf. The offlap breaks of the IPW deposits are marked with black discontinuous lines.

and dated. The ages of $\mathrm{H}$-units are: $\mathrm{H}_{1}$ : ca. $7400-6000$ cal yг BP; $\mathrm{H}_{2}$ : $5400-4200 \mathrm{cal}$ yr BP; $\mathrm{H}_{3}: 4200-3000 \mathrm{cal}$ yr BP; $\mathrm{H}_{4}: 2700-1900 \mathrm{cal}$ yr BP; $\mathrm{H}_{5}: 1900-1100 \mathrm{cal}$ yr BP; $\mathrm{H}_{6}$ : ca. $500 \mathrm{cal}$ yr BP to present. The regularity of progradation in Roquetas suggests a decadal periodicity for the deposition of a beach-ridge and the adjacent swale that has been related to variations of solar activity and with fluctuations of the
North Atlantic Oscillation (NAO) index. At a larger scale, the progradation of H-units correlates well with periods, which show comparatively high sea levels, increased intrusion of Atlantic Superficial Water (ASW), stronger winds from west and south-west, and increased sediment input to the coast. This is observed at least since the beginning of $\mathrm{H}_{2}$ (ca. 5400 cal yr BP). In contrast, the boundaries of

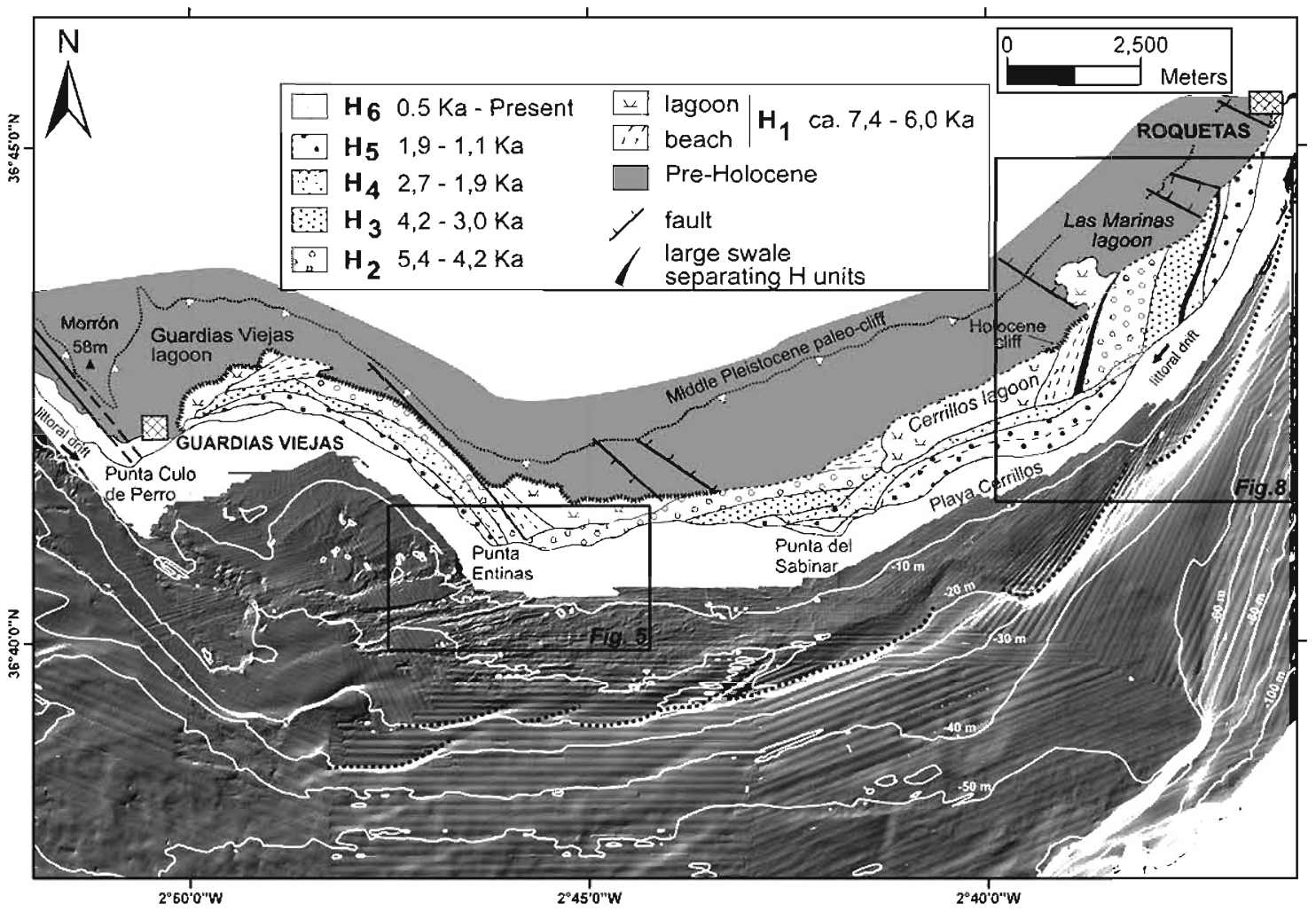

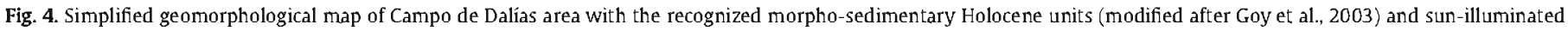
bathymetric map on the inner continental shelf. The offlap breaks of the IPW deposits are marked with black discontinuous lines. Box: area shown in Fig. 5. 


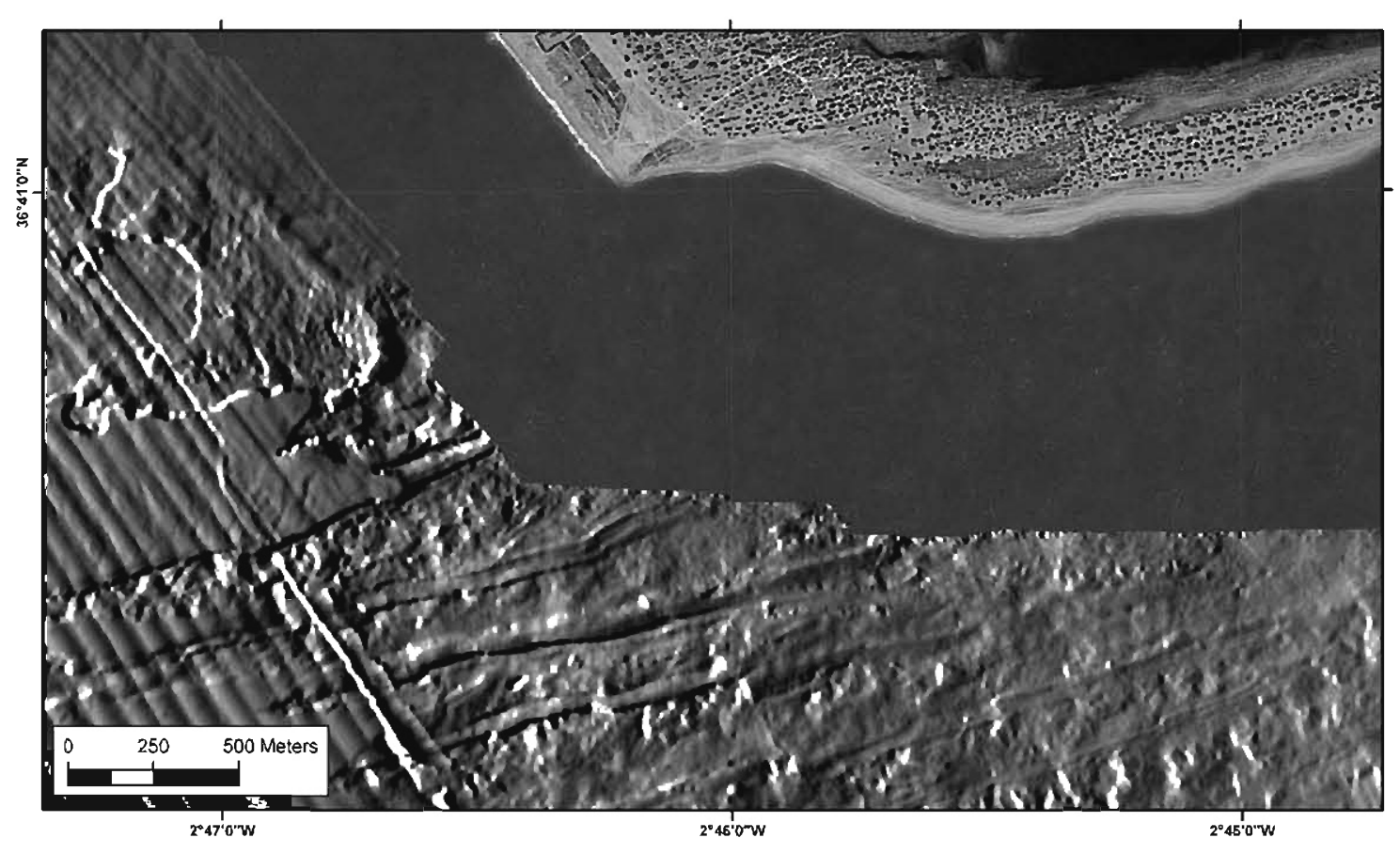

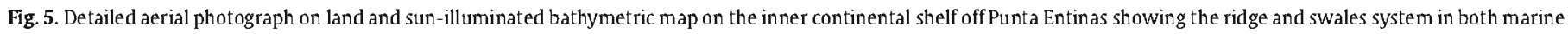
and terrestrial environment. See location in Fig. 4.

H-units correspond to periods of increased aridity with relativelylower sea level, reduced sediment input, reduced intrusion of ASW and weaker $\mathrm{W}-\mathrm{SW}$ winds. The duration of $\mathrm{H}$-units suggests a quasimillennial periodicity for their deposition.

Estimated changes of relative mean sea level (MSL) during the Holocene do not exceed $1.3 \mathrm{~m}$. A major change of littoral drift is observed at ca. $2.7 \mathrm{Ka}$, in the limit $\mathrm{H}_{3}-\mathrm{H}_{4}$, when the action of $\mathrm{W}-\mathrm{SW}$ winds increased as compared with the easterlies.

Unit $\mathrm{H}_{4}$ is separated from $\mathrm{H}_{3}$ by a large swale in the eastern side of Campo de Dalias (south Roquetas). Major erosion occurred in the southern sector (Playa Cerrillos) as evidenced by a change of the direction of progradation and an erosional escarpment cutting across unit $\mathrm{H}_{1}$ and $\mathrm{H}_{2}$. In the north-eastern part, near Roquetas, only one set of beach ridges is observed at the surface evidencing major erosion prior to deposition of $\mathrm{H}_{5}$. However, trenches excavated in the area showed that deposits of $\mathrm{H}_{4}$ extend seaward below the erosional surface and the younger $\mathrm{H}_{5}$. This implies that erosion of $\mathrm{H}_{4}$ did not proceed too far below mean sea level, as confirmed by the preservation of the corresponding IPW in the nearshore.

Unit 6 is limited by an erosional surface that cuts across $\mathrm{H}_{1}$ to $\mathrm{H}_{5}$. This unit is the youngest recognised and it is well exposed in Carchuna, but poorly represented in Campo de Dalías.

\subsection{The nearshore domain}

Off the coastal plains of Carchuna-Calahonda and Campo de DalíasRoquetas (Figs. 3, 4) the bathymetry of the sea floor increases gently (average slope $1^{\circ}$ ) up to $15-18 \mathrm{~m}$ and $18-22$ water depth respectively. Then the gradient increases to a relatively steep slope (1.5 to $2^{\circ}$ on average) that extends to 60-65 m water depth in Carchuna, and $35-40 \mathrm{~m}$ in Campo de Dalías. The resulting configuration is analogous to the infralittoral prograding wedge of Hernández-Molina et al. (2000), as these morpho-sedimentary units lie in the nearshore and are $1.5 \mathrm{~km}$ wide in Carchuna and up to $3 \mathrm{~km}$ in Campo de Dalías. The change in slope can be related to the transition from topset to foreset beds.

EM-3000D multibeam echo-sounder images reveal several surfaces that cut these sedimentary bodies oblique to their elongation. We interpret this as a proof that they were built by successive offlapping wedges that prograded up-longshore current, the prevailing direction of which can be easily deduced observing the arrangement of beach ridges in the adjacent coastal plains. Progradation was not purely towards the sea, more or less normal to the shoreline, as implicitly assumed for the typical IPW by Hernández-Molina et al. (2000), and Lobo et al. (2005), but oblique or parallel to the shore (Figs. 3, 4). Putting together the observations in the nearshore and on land, it is evident that there

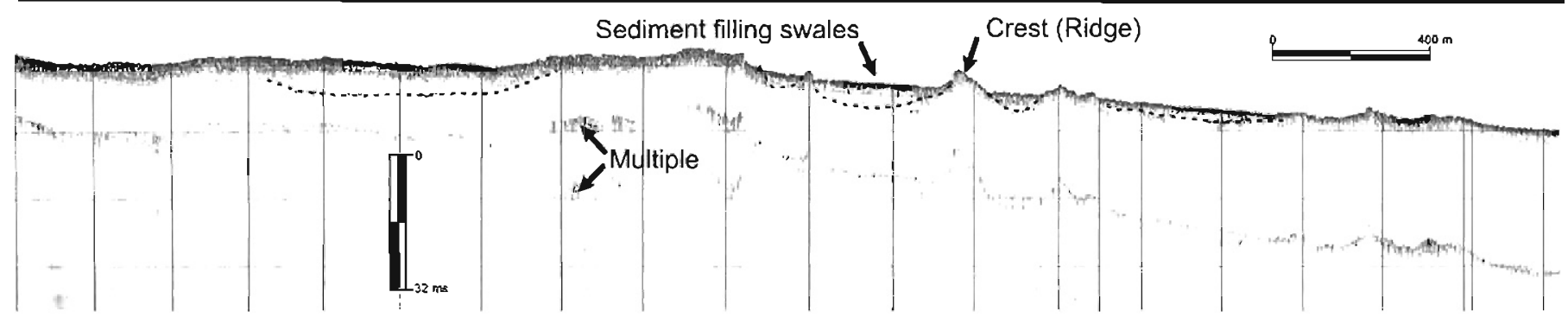

Fig. 6. TOPAS seismic profiles, showing the outcropping ridges and partial filling of swales with sediment. See location in Fig. 2. 

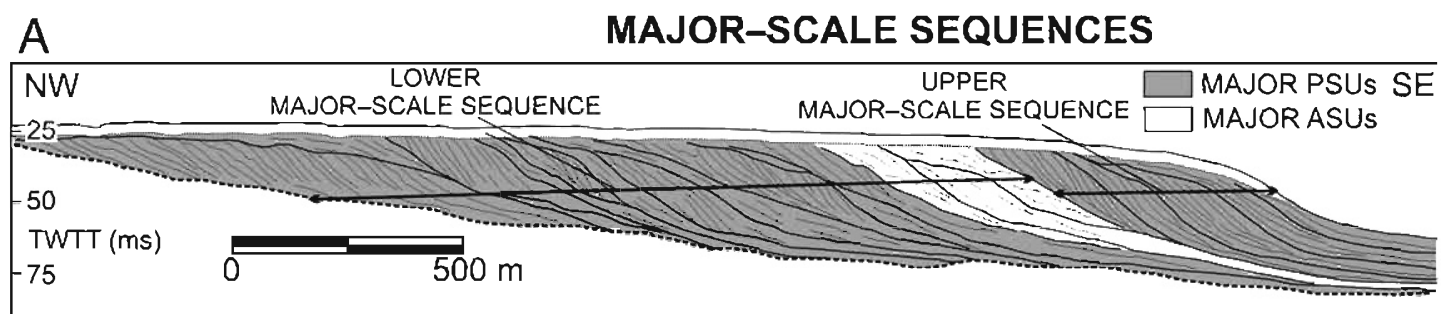

B MIDDLE-SCALE SEQUENCES

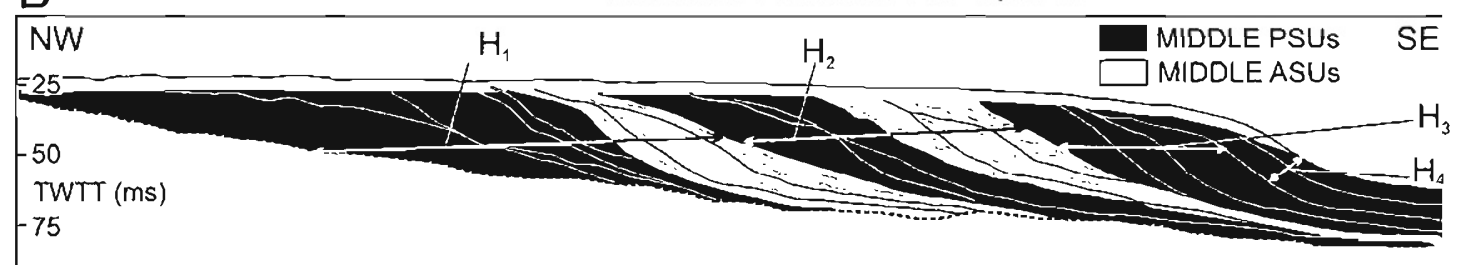

C

MINOR-SCALE SEQUENCES

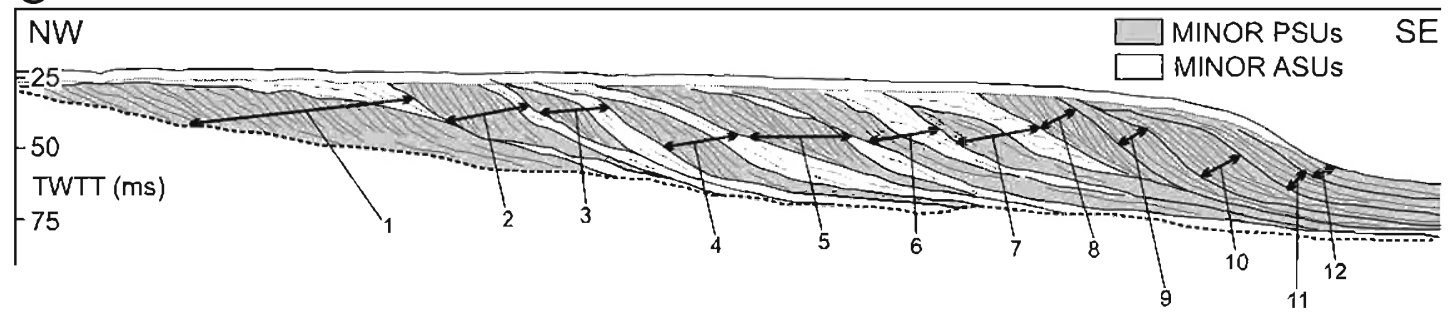

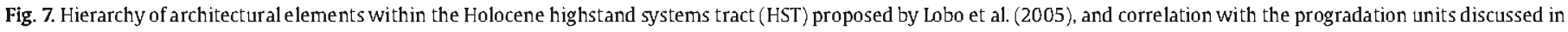

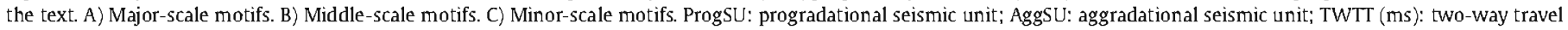
time (milliseconds).

is lateral continuity between the morpho-sedimentary units in both domains.

There is a ridge and swale system in the nearshore off Punta Entinas (Figs. 4, 5). They occur at depths of 8 to $22 \mathrm{~m}$, covering an area of $19 \mathrm{~km}^{2}$. In plan view these features vary more or less regularly and are oriented in SW-NE direction. Successive ridges are separated by a narrow depression or swale, which locally can be very wide. The height of crests ranges from 1 to $4 \mathrm{~m}$, with wavelengths between 170 and $200 \mathrm{~m}$. Ridges are seismically reflective, whereas thin layers of sediments are deposited in the swales (Fig. 6).

\section{Discussion}

The original description of the infralittoral prograding wedge (Hernández-Molina et al., 2000) states that internally it is characterized by an upward and outward-prograding sedimentary wedge with downlap at the lower boundary, toplap at the upper boundary and common downlap internal surfaces. Very high-resolution seismic and sequence stratigraphy analyses allow differentiating two internal seismic units within the IPW: (1) a lower wedge-shaped progradational unit with a sigmoid-oblique configuration, becoming transparent in a seaward direction, and (2) an upper wedge-shaped progradational unit with an oblique-tangential configuration. These authors assigned these subunits ages of 6500 to $5200 \mathrm{cal} \mathrm{yr} \mathrm{BP}$ and $3700 \mathrm{cal} \mathrm{yr} \mathrm{BP}$ to present respectively. They also assumed that these two configurations represent two episodes of progradation during the Holocene, related to minororder, asymmetrical relative sea-level fluctuations (6th-order cycles) that modulated the Late Holocene sea-level highstand.

In contrast, the observations presented in this paper indicate that the internal structure of IPWs can be much more complex owing to a lateral accumulation of individual prograding wedges related to a complex story of progradation recognized in the coastal plain, particularly in coastal segments with significant longshore transport. It is suggested here that at least some of the discontinuity surfaces depicted in Figs. 3 and 4 of Hernández-Molina et al.'s (2000) paper are actually equivalent (seen in section) of those found in our Figs. 3 and 4 , which are presented in plan view. In short, the IPW of a given coast is actually the result of the accumulation of smaller sedimentary units that record the varying conditions of sea level (recorded as minor fluctuations), sediment supply and coastal dynamics in the area during a certain time span.

In this sense, Lobo et al (2005) studied the internal structure of Holocene highstand shallow-marine deposits with higher resolution (Fig. 7). They concluded that the complex internal architecture of these deposits suggests the existence of a hierarchical pattern of environmental fluctuations: a) two major-scale motifs, that could correspond with the two seismic units of Hernández-Molina et al. (2000), b) four intermediate-scale motifs that the authors correlate with the spit-bar units $\mathrm{H}_{1}$ to $\mathrm{H}_{4}$ from Zazo et al. $(1994,1996)$ and c) twelve minor-scale motifs relate with groups of sets composing prograding units (H-units) (Goy et al., 2003). So, the IPWs described in this paper could be correlated with the intermediate-scale motifs of Lobo et al. (2005) but in this case, the stacking model has a higher lateral (i.e., parallel to the coast) than offshore (i.e., at right angles to the shore) component owing to more significant longshore current.

Regarding the lateral continuity of $\mathrm{H}$-units into IPWs, it is tempting to simply connect and correlate each $\mathrm{H}$-unit with the IPW placed more closely in a seaward direction. However, some precautions should be taken because the picture may change according with the pattern of progradation of the coastal plain. Also, the internal structure and stratigraphical architecture of units are different from the terrestrial to the adjacent marine domain and correlation needs some conceptual thinking (Fig. 8).

In Carchuna (Fig. 3) tracing the $\mathrm{H}$-units exposed on land into the nearshore, where they connect with IPWs, leads to a few considerations.

The oldest IPWs preserved off Carchuna are easily correlated with, at least, the $\mathrm{H}_{3}$ unit (sensu Goy et al., 2003) aged $4200-3000$ cal yr BP. A radiocarbon sample confirms the existence of unit $\mathrm{H}_{4}$ (2700 to $1900 \mathrm{cal}$ 


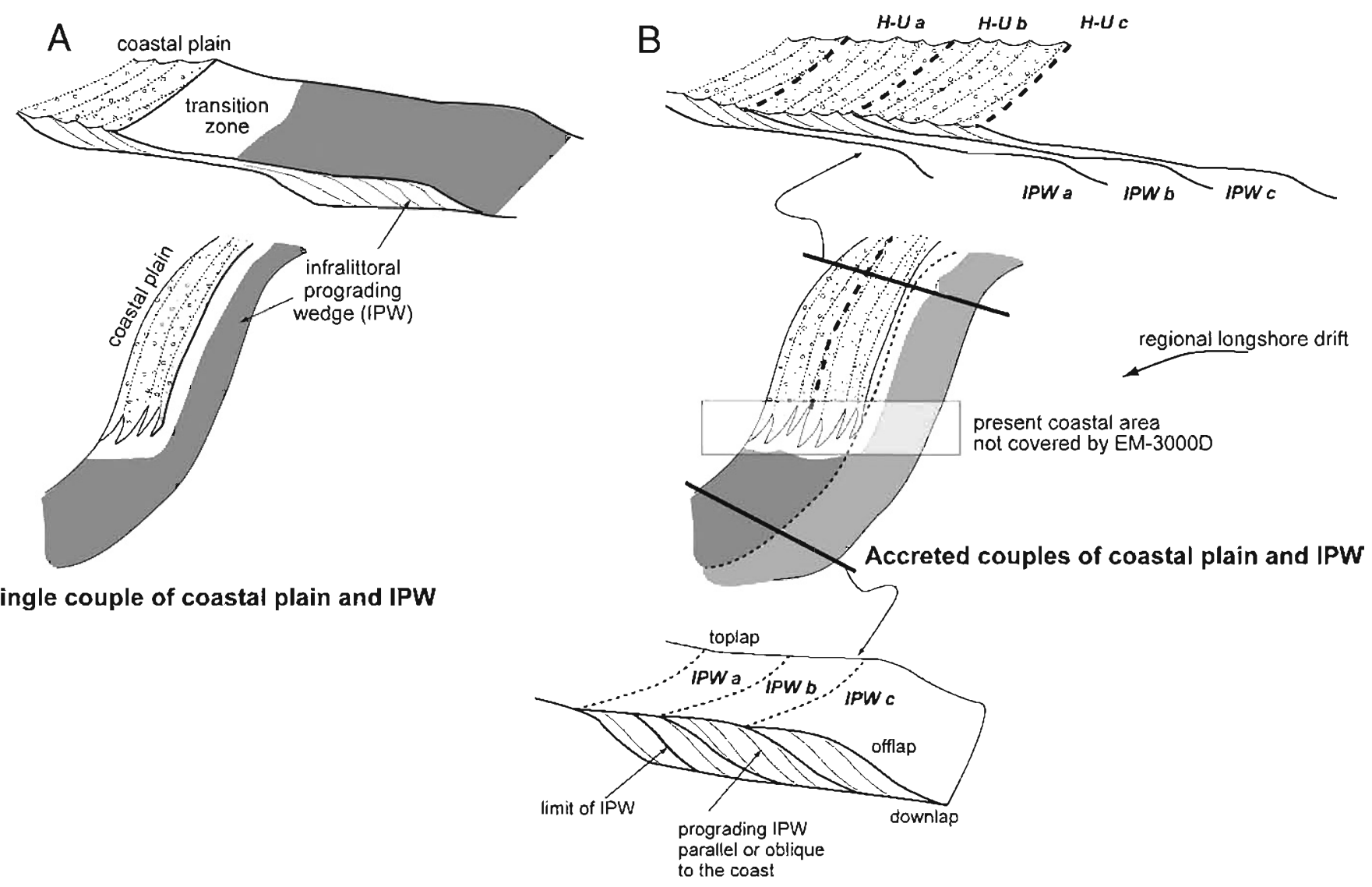

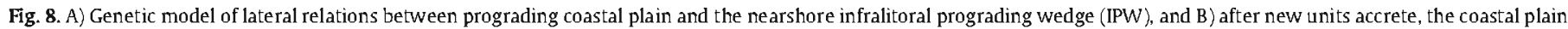
progressively overlaps a part of the previous IPWs, and correlation becomes more problematic.

yr BP). No samples of $\mathrm{H}_{5}(1900-1100 \mathrm{cal}$ yr BP) were dated but it is logical to think that it is also present, although not clearly separated from $\mathrm{H}_{4}$. However the occurrence of a reworked shell ( $\mathrm{CH} .1$, age $1050 \mathrm{cal}$ yr BP, Lario et al., 1999) in deposits of $\mathrm{H}_{6}$ age (500 cal yr BP to Present) suggests that erosion may have removed a significant part the record, albeit not a prominent erosional surface is observed in air photographs, as discussed later.

The present Carchuna beach cuts the southern extremity of the coastal plain, but erosion has not significantly affected the IPWs, meaning that sediment remains essentially untouched below a few meters water depth.

The size and lateral extent of IPWs has decreased steadily during the time span recorded in Carchuna (Fig. 3), but there is a marked reduction in size at the transition from $\mathrm{H}_{3}$ to $\mathrm{H}_{4}$ (ca. 3000-2700 cal yr BP), and a new noticeable reduction occurs between the IPWs roughly correlatable with $\mathrm{H}_{4}$ (?) and $\mathrm{H}_{5}$ (ca. 1900 cal yr BP). These features suggest a progressive reduction in sediment supply with major changes between $\mathrm{H}_{3}$ and $\mathrm{H}_{4}$ and around $\mathrm{H}_{5}$, probably related with the successive reduction of sediment supply to the coastal budget as the ephemeral rivers flowing into the former Carchuna embayment were separated from the sea during the eastward progradation of the coastal plain.

Correlation of the Campo de Dalias plain and the nearshore IPWs is somewhat problematic owing to the arch-shaped morphology of the $\mathrm{H}$-units in this coastal tract. Here, curved prograding units accrete seawards but the corresponding IPW form a tail-like structure that adapts to the prevailing coastal drift (Fig. 4). As a result, H-units accrete more or less concentrically whereas each IPWs adapts to the previous one forming an offlap scheme, with the younger units attached to the side facing up-current of the longshore drift. As in Carchuna, a noticeable reduction of the surface occupied by the IPW is observed in the transition $\mathrm{H}_{3}-\mathrm{H}_{4}$. It is interesting to note that $\mathrm{H}_{4}$ accumulated after a major erosional event that truncated the ample cuspate units $\mathrm{H}_{2}$ and $\mathrm{H}_{3}$. The age of this event is ca. $2700 \mathrm{cal}$ yr BP, i.e. in Phoenician times, and has been reported in many other coastal localities of southern Spain, where it has been interpreted as the result of a major change in the direction of prevailing winds and littoral drift (Borja et al., 1999; Dabrio et al., 2000; Goy et al., 2003).

A submerged morpho-sedimentary unit visible underwater some $2 \mathrm{~km}$ SW of Punta del Sabinar(Fig. 4) may correspond to partly preserved remains of the $\mathrm{H}$-unit 3 or 4 which shallower parts were eroded during later stages.

The origin of this unit is not easy to determine, as the EM-3000D multibeam data do not extend to the shoreline. We suggest here that these are relict forms that are difficult to connect to a particular $\mathrm{H}$ unit. Considering the overall evolution of the Campo de Dalías presented by Goy et al. (2003), we suggest that they are submarine bars laterally equivalent to the $\mathrm{H}_{5}$ unit during which major coastal erosion took place. It is likely that a part of the relatively-large volumes of sediment removed was diverted to the nearshore where it accumulated as shallow bars. Nevertheless, in the absence of accurate radiometric dating, a younger origin cannot be discarded; in this case these bedforms would be modern accumulations.

\section{Conclusions}

Prograding coastal plains in southern Spain are laterally connected to nearshore deposits. Growth phases of progradation and erosion or reduced growth distinguished in the coastal plains can be correlated with units in the nearshore identified as infralittoral prograding wedges.

The IPW is a complex morpho-sedimentary unit whose internal structure is closely linked to the pattern of progradation of the adjacent coastal plain. 
In coastal segments with significant longshore currents, particularly when neat littoral drift is active, the IPW is composed of several minor units arranged in offlap, which accrete parallel or oblique to the main shoreline.

Correlation of progradation units in the coastal plain (H-units, sensu Goy et al., 2003) and subunits in the IPW requires special care depending on the local arrangement of morpho-sedimentary units. Direct tracing of apparently laterally-connected units can be misleading.

The internal organization of coeval units in the coastal plain and the nearshore is governed by progradation, but the pattern is different and the preservation potential is much higher for the IPW, as it largely remains out of reach of the coastal erosion when fluctuation of sea level are small, as is the case of the Holocene of southern Spain.

No implications of age can be derived directly from the internal structure of the IPW, as the number of subunits will greatly vary from place to place depending on local factors, magnitude of sea-level oscillations, and sediment supply.

\section{Acknowledgements}

The geophysical information of marine areas was provided by research project: "Estudio Geológico de la Plataforma Continental Española”, funded by "Secretaría General de Pesca Maritima, Ministerio de Agricultura, Pesca y Alimentación". Research on land was funded by Projects CGL 2005-01336/BTE and CGL 2005-04655/BTE. This is a contribution to IGCP projects 464 (Continental shelves during the last glacial cycles: knowledge and applications) and 495 (Quaternary land-ocean interactions: driving mechanisms and coastal responses), and to Work Group UCM: "Paleoclimatology and Global Change (910198)". We are especially grateful to Prof. Dr. Dorrik Stow for his comments and English revisions. Also, we would like to thank the referees: Prof. Dr. Hernández-Molina and Prof. Dr. Joao Manuel Alveirinho Dias for their interest and dedication, as evidenced by the suggested recommendations and corrections.

\section{References}

Borja, F., Zazo, C., Dabrio, C.J., Díaz del Olmo, F., Goy, J.L., Lario, J., 1999. Holocene aeolian phases and human settlements along the Atlantic coast of southern Spain. Holocene $9,333-339$.

Dabrio, C.J., Zazo, C., Goy, J.L., Sierro, F.J., Borja, F., Lario, J., González, J.A., Flores, J.A., 2000. Depositional history of estuarine infill during the last postglacial transgression (Gulf of Cádiz, southern Spain). Mar. Geol. 162, 381-404.
Goy, J.L., Zazo, C., Dabrio, CJ., 2003. A beach-ridge progradation complex reflecting periodical sea-level and climate variability during the Holocene (Gulf of Almeria, Western Mediterranean). Geomorphology 50, 251-268.

Herburn, G.H., la Violette, P.E., 1990. Variations in the structure of the anticyclone gyres found in the Alboran Sea. J. Geophys. Res. C.2, 1599-1613.

Hernández-Molina, F.J., 1993. Dinámica sedimentaria y evolución durante el Pleistoceno Terminal-Holoceno del margen noroccidental del Mar de Alborán. Modelo de estratigrafia secuencial de muy alta resolución en plataformas continentales. Ph. D. Universidad de Granada. 617 pp.

Hernández-Molina, FJ., Lobo, FJ., 2005. El margen continental del Golfo de Cádiz. In: Martín-Serrano, A (Ed.), Mapa Geomorfológico de España y del margen continental a escala 1:1.000.000. Instituto Geológico y Minero de España, pp. 211-218.

Hernández-Molina, F.J., Somoza, L., Rey, J., Pomar, L, 1994. Late Pleistocene-Holocene sediments on the Spanish continental shelves; model for very high resolution sequence stratigraphy. Mar. Geol. 120, 129-174.

Hernández-Molina, F.J., Fernández-Salas, L.M., Lobo, F.J., Somoza, L., Díaz del Río, V., Alveirinho Dias, J.M., 2000. The infralittoral prograding wedge: a new large-scale progradational sedimentary body in shallow marine environments. Geo-Mar. Lett. 20, 109-117.

IHM-Instituto Hidrográfico de la Marina, 1983. Derrotero de las Costas del Mediterráneo. Servicio de Publicaciones de la Armada, Madrid, pp. 102-114.

Lario, J., Zazo, C, Goy, J.L., 1999. Fases de progradación y evolución morfosedimentaria de la flecha litoral de Calahonda (Granada) durante el Holoceno. Estud. GeoL 55, 247-250.

Lobo, FJ., Fernández-Salas, L.M., Hernández-Molina, EJ., González, R., Dias, J.M.A., Díaz del Río, V., Somoza, L., 2005. Holocene highstand deposits in the Gulf of Cadiz, SW Iberian Peninsula: a high-resolution record of environmental changes. Mar. Geol. 219, 119-141.

Rodríguez-Ramírez, A., Cáceres, L., Rodríguez-Vidal, J., Cantano, M., 2000. Relación entre el clima y génesis de crestas/surcos de playa en los últimos cuarenta años (Huelva, Golfo de Cádiz). Rev. Cuat. Geomorfol. 14, 109-113.

Somoza, L., Barnolas, A., Arasa, A. Maestro, A, Rees, J.G., Hernández-Molina, F.J., 1998. Architectural stacking patterns of the Ebro delta controlled by Holocene highfrequency eustatic fluctuations. delta lobe switching and subsidence processes. Sediment. Geol. 117, 11-32.

Swift, D.J.P., Thorne, J.A., 1991. Sedimentation on continental margins, I: a general model for shelf sedimentation. In: Swift, D.J.P., Oertel, G.F., Tillman, R.W., Thorne, J.A. (Eds.), Shelf Sands and Sandstone Bodies. Geometry, Facies and Sequence Stratigraphy. IAS Spec. Publ. 14, Blackwell Scientific, Oxford, pp. 3-31.

Swift, D.J.P., Ludwick, J.C., Boehmer, W.R., 1972. Shelf sediment transport, a probability model. In: Swift, D.J.P., Douane, D.B., Pilkey, O.H. (Eds.), Shelf Sediment Transport: Process and Pattern. Dowden Hutchinson \& Ross, Strassbourg, PA, pp. 195-223.

Swift, D.J.P., Phillips, S., Thorne, J.A., 1991. Sedimentation on continental margins, IV: lithofacies and depositional sequences. In: Swift, D.J.P., Oertel, G.F., Tillman, R.W., Thorne, J.A. (Eds.), Shelf Sands and Sandstone Bodies. Geometry, Facies and Sequence Stratigraphy. IAS Spec. Publ. 14, Blackwell Scientific, Oxford, pp. 89-152.

Zazo, C., Goy, J.L., Somoza, L., Dabrio, C.J., Belluomini, G., Improta, J., Lario, J., Bardají, T., Silva, P.G., 1994. Holocene sequence of sea-level fluctuations in relation to climate trends in the Atlantic-Mediterranean linkage coast. J. Coastal Res. 10, 933-945.

Zazo, C, Goy, J.L, Lario, J., Silva, P.G., 1996. Littoral zone and rapid climatic changes during the last 20,000 years. The Iberia study case. Z. Geomorphol. 102, 119-134. 